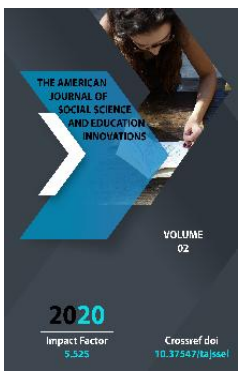

\title{
The Role Of Metaphors In The System Word Groups Of The Languages
}

\author{
Ernazarova Hilola Ergashevna \\ Teacher Of Kokand State Pedagogical Institute, Uzbekistan
}

Journal Website:

http://usajournalshub.c

om/index,php/tajssei

Copyright: Original

content from this work

may be used under the

terms of the creative

commons attributes

4.0 licence.

\section{ABSTRACT}

In this article, we give the reason why in the process of formation of imitation words, a person first observes the environment and forms words based on the phonetic potential of his language in the expression of certain sounds in it.

\section{KEYWORDS}

Noun, adjective, determiner, verb, descriptive words, imitation words.

\section{INTRODUCTION}

Special works on the study of imitation words in turkology appeared after the twenties of the last century, and in most Turkic languages the category of imitation words has been developed to one degree or another. In Uzbek linguistics, this issue was not studied as a separate object of study until the 1960 s. Until then, in Uzbek grammars and manuals, imitation words were given very little space, and in many of them imitation words were shown as an integral part of pronouns.

Since the second half of the last century, the issue of metaphors has attracted the attention of our scientists. They made some observations on the subject and expressed their views on this or that situation. In particular, AN Kononov in his work "Grammar of the Uzbek language" identifies descriptive 
words as a form of pronouns, and in his work "Grammar of the modern Turkish literary language", published in 1956, distinguishes them as a separate word group. Thus, although AN Kononov in his previous works described descriptive words as a type of pronouns, in 1956 he came to the conclusion that they should be divided into independent word groups, and in "Grammar of modern Uzbek literary language" he strongly states this conclusion.

\section{MATERIALS AND METHODS}

Although A. Gulyamov in his textbooks for schools, in his book "Introduction to the morphology of the Uzbek language" used metaphors as a kind of encouragement, in his speech at the republican conference on improving the teaching of Uzbek in schools in August 1957, it was necessary to separate metaphors. records. U.Tursunov and J.Mukhtorov, S.Mutallibov, S.Usmanov in their works separate descriptive words from pronouns and consider them as a separate word group. In 1956, S. Mutallibov published an article on imitation in the "Teachers' Newspaper". In this article, both sound imitation words and descriptive words are referred to as sound imitation words. There are also some very confusing points in the case. However, S. Mutallibov clarified this issue in his later essays. But in both cases there is some confusion in the interpretation of some examples of descriptive words. For example, there are cases when words that mimic more sounds are confused with words that describe the action and situation. It is a proof of our opinion that in his article he used the words glitter, glitter, lim-lim, gimir-gimir, and in his essays he called words such as dikillamak as imitation of sound. The words quoted should be considered as descriptive words, not words that imitate the sound. S.
Mutallibov combines words that imitate sound and situation and describes them as follows:

"Words that conditionally mimic the sounds that come from the movement of animals, creatures, birds, and people are called sound mimics."

This definition does not embody all the features of metaphors. This definition does not comment on words that mimic the situation.

The author's idea of making imitation words is also not without objections. First of all, it is necessary to distinguish between the construction of imitation words and the construction of other word groups from them, that is, they should not be considered as a phenomenon.

The researcher argues that words that mimic sound have morphological features, but more often work on the construction of other word groups, such as verbs, nouns, and adjectives, from imitation words.

Speaking about the types of imitation words, S. Mutallibov writes: "Sound imitation words are divided into two according to their structure:

a) Words that are conditionally imitated by the sound heard: to fall asleep, to walk;

b) Words made conditionally imitating the appearance of things and events: yaltyult, lim-lim

For the first time in the history of Uzbek linguistics, the study of descriptive and imitation expressions was covered in detail by linguist R. Kungurov in his book "Descriptive words in the Uzbek language." In his work, Kungurov describes the words that describe 
the situation as descriptive words and explains his study of these expressions as follows: "In Turkology, some scholars equate descriptive words with sound imitations and treat them as' image imitation words '. descriptive words and phonetic imitation words are very close to each other as a grammatical category in terms of phonetics, morphology and syntax. However, there are many peculiarities that make it difficult to consider image words as imitation words: semantically to sound Imitations occur as a result of imitating the sounds made by people, birds and animals, various other animals and inanimate objects. They are mainly associated with hearing. Descriptive words are formed as a result of seeing and imagining the state, movement and appearance of people and other inanimate objects. images indicates ini. At this point, we have found it necessary to dwell on some of the ideas expressed in the parable in another textbook. In most of the above works, repeated imitation words in the same form (such as taq-taq, meow-meow) are considered as repeated imitation words, and some phonetically repeated imitation words are considered as double imitation words (such as apil-tapil, givir-shivir)

In the work of U.Tursunov, J.Mukhtorov, Sh.Rakhmatullayev "Modern Uzbek literary language" "Repeated imitation words are formed on the basis of repetition of these words, there is a phonetic change, the word can be repeated several times: pikir-pikir, paqpuq, tars -like tours.

In a pair of imitation words, however, several imitation words are paired: like taka-tum-tak, pluk-sand-prr.

\section{RESULT AND DISCUSSION}

Before studying the features of their representation in dictionaries, we have focused on the history of the study of imitation words in Uzbek linguistics, its reflection in the existing scientific and theoretical literature and textbooks. The next chapter discusses the metaphors that can be found in dictionaries. As a result of $R$. Kungurov's scientific observations on descriptive words, "Some comments on descriptive words in Uzbek language", "On the phonetic features of descriptive words in Uzbek literary language", "On the study of descriptive words in Uzbek language", "On lexical features of descriptive words" semantic classification of descriptive words in modern Uzbek language ". He defended his dissertation in 1962 and published a monograph "Descriptive words in the Uzbek language" in 1962, summarizing the general description of descriptive words in Uzbek linguistics, their place in the system of word formation, phonetic, lexical, grammatical, syntactic features. was found. A brief glossary of descriptive words is also given at the end of this work. In the part of the monograph entitled "From the history of the study of descriptive words" R. Kungurov dwells on the study of descriptive words in turkology, and to some extent comments on the views of turkologists on descriptive words. Giving general ideas about descriptive words in the section "General characteristics of descriptive words", he concludes on descriptive words as follows:

a) Have their own lexical meanings;

b) Can raise the level of general impression in a person. All a collective that speaks the same language basically understands them the same way;

c) Has its own structure, form; 

d) Simply comes mainly with auxiliary
verbs;

e) D) can act as a specific part of speech and interact with other parts of speech. An imitation with this feature can be considered a word. Also, in this section, on the basis of Uzbek language materials, the close, similar features of pronouns and descriptive words are as follows:

Descriptive words and urges do not indicate the name of the image, sound, and emotion of the action, but are a direct expression of them. Pronouns and descriptive words (without constructive affixes) are taken as nouns. For example, oh, uh, condition, gurs, milt, yalt-yalt, jildir-jildir and so on. The lack of nominative character in both categories distinguishes them from other categories, categories.

In the work "Modern Uzbek literary language" written by $\mathrm{E}$. Begmatov, published under the general editorship of G.Abdurahmanov, the metaphors are given under the term "Descriptive words" and relatively more detailed information is given. It defines descriptive words as follows: "Words formed by imitating the various sounds in the objective world and the descriptive states of motion of things and events are called descriptive words."

\section{CONCLUSION}

Descriptive words are divided into two in terms of meaning: imitation words and descriptive words; studied according to their structure into three: simple, repetitive, and double descriptive words. Some phonetic features of descriptive words, the role of descriptive words in the word-formation system, the phenomenon of jumping in them (such as noise $+\mathrm{i}$ ) and their important syntactic functions are also considered.

The fact that descriptive words are not enriched at the expense of other word groups means that new descriptive words are formed from them by means of certain grammatical forms (such as shir-t-shirt, shir-q-shirk, shik-irshiqir, shar-t-shart). interpreted as a sign.

\section{REFERENCES}

1. International Journal of Basic Sciences and Applied Research Vol, 3 (SP), 219225, 2014//Available online athttp://www.isicenter.org.-P.221

2. uz.denemetr.com

3. www.hozir.org

4. www.owlcation.com

5. www.englishlive.ef.com 